\title{
Current trends and prospects of tidal energy technology
}

\author{
M. S. Chowdhury ${ }^{1,4} \cdot$ Kazi Sajedur Rahman ${ }^{2} \cdot$ Vidhya Selvanathan $^{2}$. \\ Narissara Nuthammachot ${ }^{1} \cdot$ Montri Suklueng $^{5}$ - Ali Mostafaeipour ${ }^{7,8} \cdot$ Asiful Habib $^{9}$. \\ Md. Akhtaruzzaman ${ }^{2} \cdot$ Nowshad Amin $^{3} \cdot$ Kuaanan Techato ${ }^{1,4,6}$ (D)
}

Received: 26 November 2019 / Accepted: 25 September 2020 / Published online: 6 October 2020

(c) Springer Nature B.V. 2020

\begin{abstract}
Generation of energy across the world is today reliant majorly on fossil fuels. The burning of these fuels is growing in line with the increase in the demand for energy globally. Consequently, climate change, air contamination, and energy security issues are rising as well. An efficient alternative to this grave hazard is the speedy substitution of fossil fuel-based carbon energy sources with the shift to clean sources of renewable energy that cause zero emissions. This needs to happen in conjunction with the continuing increase in the overall consumption of energy worldwide. Many resources of renewable energy are available. These include thermal, solar photovoltaic, biomass and wind, tidal energy, hydropower, and geothermal. Notably, tidal energy exhibits great potential with regard to its dependability, superior energy density, certainty, and durability. The energy mined from the tides on the basis of steady and anticipated vertical movements of the water, causing tidal currents, could be converted into kinetic energy to produce electricity. Tidal barrages could channel mechanical energy, while tidewater river turbines can seize the energy from tidal currents. This study discusses the present trends, ecological effects, and the prospects for technology related to tidal energy.
\end{abstract}

Kuaanan Techato

Kuaanan.t@psu.ac.th

1 Faculty of Environmental Management, Prince of Songkla University, Songkhla, Thailand

2 Solar Energy Research Institute, Universiti Kebangsaan Malaysia, 43600 Bangi, Selangor, Malaysia

3 Institute of Sustainable Energy, Universiti Tenaga Nasional (@The Energy University), Jalan IKRAM-UNITEN, 43000 Kajang, Selangor, Malaysia

4 Environmental Assessment and Technology for Hazardous Waste Management Research Center, Faculty of Environmental Management, Prince of Songkla University, 90110 Songkhla, Thailand

5 Faculty of Environmental Management, Prince of Songkla University, Songkhla, Thailand

6 Center of Excellence on Hazardous Substance Management (HSM), Bangkok 10330, Thailand

7 Environmental Assessment and Technology for Hazardous Waste Management Research Center, Faculty of Environmental Management, Prince of Songkla University, HatYai 90110, Thailand

8 Faculty of Environmental Management, Prince of Songkla University, HatYai, Thailand

9 Higher Institution Centre of Excellence (HICoE), UM Power Energy Dedicated Advanced Center (UMPEDAC), University of Malaya, Kuala Lumpur, Malaysia 
Keywords Tidal energy $\cdot$ Current trends $\cdot$ Prospects $\cdot$ Environmental impact

\section{Introduction}

The global demand for electrical energy has quickly risen in the modern times. According to the International Energy Agency (IEA), the share of demand accounted by electrical energy rose considerably during 1990-2017, with electrical energy accounting for around $40 \%$ of the total energy utilised in 1990 and that number being expected to rise to $50 \%$ in 2030 (Jeffrey 2017). The demand for energy worldwide is primarily met by fossil fuels like natural gas, oil, and coal that accounted for $88.1 \%$ of the overall demand for energy in 2009 (oil 34.8\%, coal 29.2\%, and natural gas 24.1\%) (Kadiri et al. 2012). In 2017, production of electricity from various other sources decreased: oil $32.0 \%$, coal $27.1 \%$, natural gas $22.2 \%$, renewable energy $13.80 \%$, and nuclear $4.9 \%$ (Fig. 1) (Newell et al. 2019). Conversely, in 2018, share in electricity production altered radically in some areas; for example, electricity produced by coal decreased by around $50 \%$ over 2017 , and the share in renewable energy decreased by $3 \%$ (Newell et al. 2019). Moreover, the share of other resources like natural gas, nuclear, and oil rose swiftly.

Notably, fossil fuel reserves are likely to drain off progressively in the coming years (Kadiri et al. 2012). The prices of fossil fuels have risen intensely, and this would continue due to consumer demand and falling reserves. Moreover, the burning of fossil fuels emits greenhouse gases, especially carbon dioxide, the key reason behind climate change and global warming.

The COVID-19 pandemic of 2020 radically altered the global demand for energy (Abiad and Rosa Mia Dagli 2020). According to the International Energy Agency (IEA), the demand for energy might fall in 2020 for oil $(-9 \%)$, coal $(-8 \%)$, natural gas $(-5 \%)$, and nuclear $(-2 \%)$, while that for renewables might rise $1 \%$. Even though the uncertainties thrive, the impending GDP and electricity consumption trends are uncertain in the longer term (IEA 2020a; Dorn et al. 2020). The latest studies have indicated that the range of economic growth directions espoused by the majority of energy outlooks is extremely slimmer compared to the past records. According to IEA estimations, the emissions might fall by around 8\% in the present year, going back to the 2010 levels (IEA 2020a). Nonetheless, in the absence of major changes in municipal policies for dealing with climate change, a

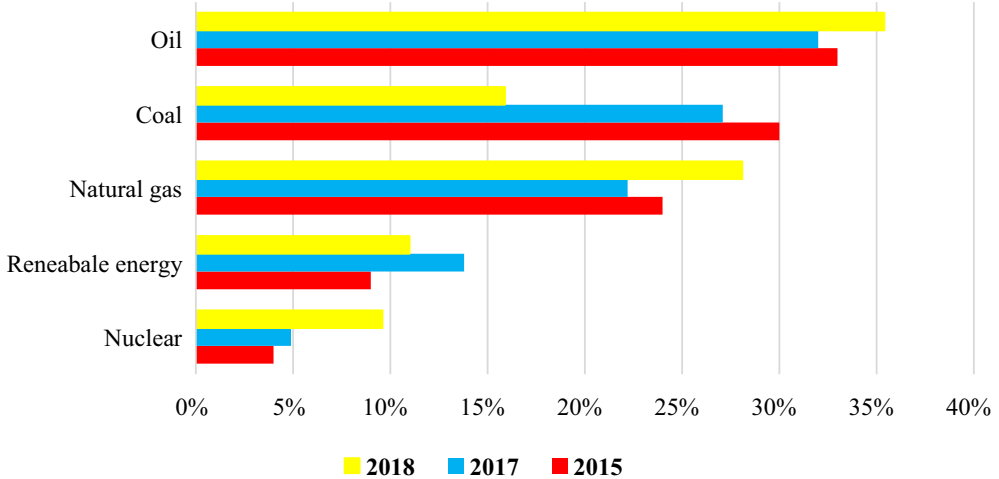

Fig. 1 World energy demand comparison from 2015 to 2018 (Newell et al. 2019) 
switch back to the economic development might indicate a retreat to greenhouse gas emissions growth.

In 2020 , the capacity for renewable electricity would fall by $13 \%$ as against 2019 , the nation's first downward movement since 2000 (Hale et al. 2020). This refers to a $20 \%$ downward revision as against our earlier estimate wherein 2020 was projected to be the best ever year for renewable power. Notably, the majority of these delayed ventures are likely to be online in 2021, triggering a bounce back of capacity additions. Consequently, 2021 is estimated to nearly touch the level of renewable capacity increases of 2019 (Hale et al. 2020). In spite of the bounce back, the joint growth in 2020 and 2021 is around 10\% lower as against the earlier IEA estimate (Fig. 2) (IEA 2020a). China and the USA are likely to witness a rise in capacity additions in 2020 and 2021 as against 2019. The discontinuing of subsidies in China and the termination of tax credits in the USA (in 2020 and 2021, respectively) (Fig. 2) is driving project development. However, both countries are likely to offer certain flexibility, permitting projects to be commissioned next year without sacrificing incentives. Consequently, wind and solar PV are expected to be reorganised and commissioned in 2021. In India, COVID-19 is worsening current challenges regarding the fiscal health of distribution firms, which play a vital part in the positioning of utility scale as well as distributed PV.

Ocean energy technology (OET) has several beneficial aspects like economic progress, supply security, and reduction of $\mathrm{CO}_{2}$ emissions. Ocean energy technology should be endorsed and given due importance to increase adoption that ultimately leads to global ocean energy marketplaces (Badcock-Broe et al. 2014). Ocean energy is renewable and depends on several aspects of ocean waves like water temperature, currents, and salinity. The moon, sun, and other celestial bodies are responsible for the formation of tides, and solar radiation, among other things. There are several aspects concerning ocean energy, namely waves, tidal currents, ocean heat, tidal barriers, and salinity gradient energy. Ocean renewable energy is noteworthy with a global installed capacity of 76 million MW, thereby

\section{0}

200

150

100

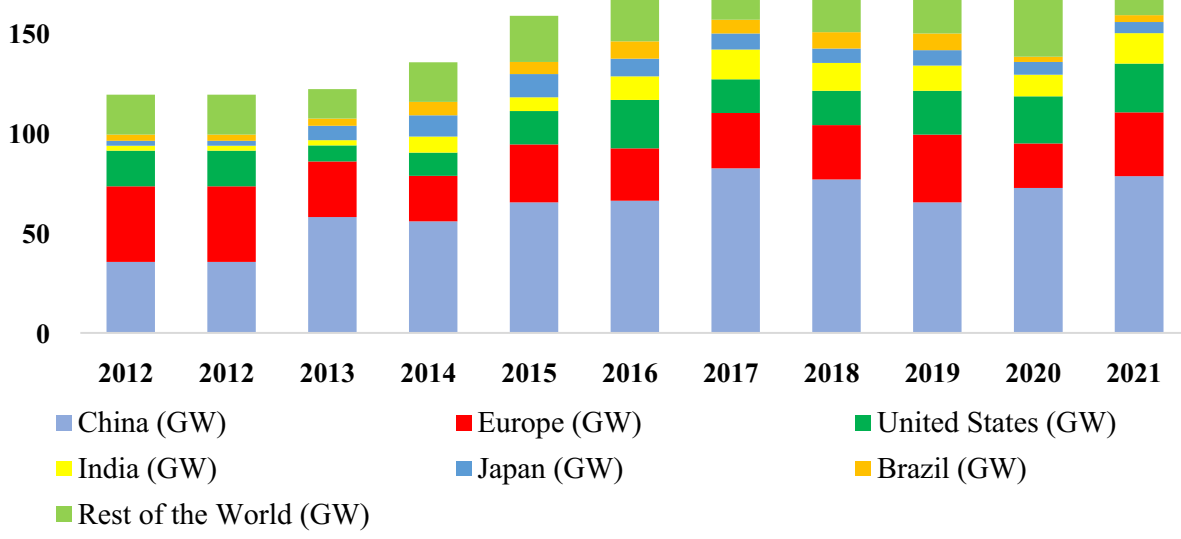

Fig. 2 World renewable electricity capacity, 2012-2021 (IEA 2020) 
reducing emissions (Behrens et al. 2015). Coastal nations are in a unique position to have energy security using clean energy and also reduce climate change (Li 2008; Behrens et al. 2015). In the global electricity scenario, ocean renewable energy has a contribution of up to $7 \%$ (Esteban and Leary 2012). In comparison, tidal stream and offshore wind techniques collectively account for about $0.75 \%$ of worldwide energy requirements (Esteban and Leary 2012). Tidal stream energy holds more potential compared to wave energy, or offshore wind energy; however, very few areas are suitable for extraction of tidal stream energy. Technology concerning the extraction of tidal stream energy is still in the nascent stage of development; however, it has massive potential to gain a significant fraction in the future energy mix for sites in: UK, Canada, France (Guillou et al. 2018; Coles et al. 2017), Norway, Spain (González-Caballín et al. 2016); Indonesia (Orhan et al. 2015), Taiwan (Chen et al. 2013), China (Gao et al. 2015), Malaysia (Lim and Koh 2010), Philippines (Buhali et al. 2012), and New Zealand (Moore and Boyle 2014). The tides in the oceans hold massive energy potential and could potentially be a prominent electrical energy source. Tidal barrages have been researched, along with other technologies, to understand how to capture ocean energy effectively. Nevertheless, tidal energy is not a commercial mainstream energy source yet but holds the potential to be exploited as a commercial renewable energy source. Additionally, tidal energy is less polluting and can produce massive energy compared to other renewable sources. Tidal current velocity can lead to high power production, given the turbine is placed at an appropriate location (Rourke et al. 2010). Globally, several roadblocks are facing the implementation of tidal energy and associated technology. For instance, turbine efficiency, cost of setting up a power plant, and social awareness are few such issues. The objective of this study is to highlight present generation trends concerning tidal energy, address related environmental concerns, and discuss future prospects and social responsibility in the tidal energy scenario. Moreover, there is a review of tidal energy policies.

\section{Current status and trend of tidal energy technology}

Technological advancement has led to the enhancement of the power produced from the ocean. There was a $13 \%$ growth in 2019 , which is remarkably higher than the growth in the three preceding years. However, there needs to be a speedy deployment of this technology for it to be as per the Sustainable Development Scenario (SDS), thereby an annual growth of 23\% is required through 2030 (Adrian 2020). Research and development, along with state policy, is necessary to achieve the required cost reduction and facilitate massive deployment. Electrical power generated from marine sources saw an increase of $13 \%$ in 2019 (Adrian, 2020). Nevertheless, the status of marine power is still "not on track" since it is too far from the requirements of the Sustainable Development Scenario (SDS), where an annual growth rate of $23 \%$ is required till 2030 (IEA 2020b) (Fig. 3). Several countries like Canada, the UK, China, and Australia have already functioning sophisticated marine energy projects of $10 \mathrm{~kW}$ to $1 \mathrm{MW}$ capacity (IEA 2020b). Nevertheless, such small-scale and demonstrative projects are expensive because they do not achieve the required economies of scale to be cost-efficient.

The rising and falling waters of the ocean determine the extent of tidal power potential. Along the shore, neap and spring tides having a range of 4-12 $\mathrm{m}$ have a power production potential of 1-10 MW/km (Khan et al. 2017). Estimation for tidal power may be conducted 


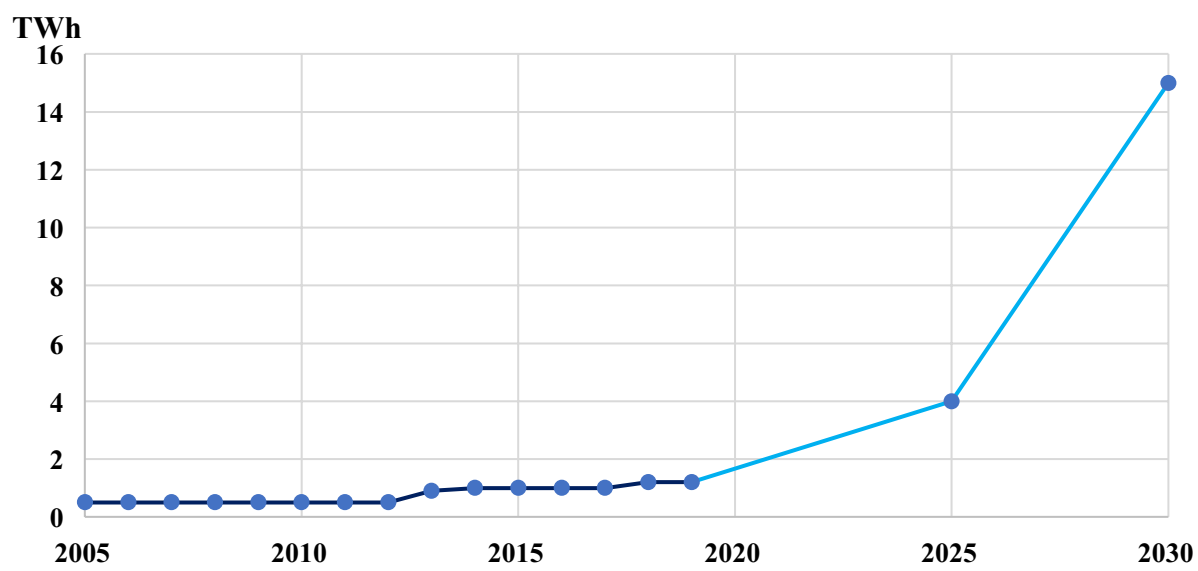

Fig. 3 Ocean power generation scenario, 2000-2030 (IEA 2020b)

using an estuary located on the seashore. The energy potential for a tide height of R meter above the sea datum line is specified as:

$$
E=\rho g \int_{h=0}^{h=R} h A \mathrm{~d} h
$$

where $\rho$ denotes the density of seawater $\left(\mathrm{kg} / \mathrm{m}^{2}\right)$ and $\mathrm{g}$ denotes the gravitational constant $\left(9.81 \mathrm{~m} / \mathrm{s}^{2}\right)$. Given that the tidal range equals the difference between the maximum and minimum basin levels, an average water discharge of $(Q=A H / t)$ flowing through the turbine will do work (falling from height $h$ ) as specified by the following equation:

$$
P=\rho Q h \text {. }
$$

Considering 705 annual tidal cycles with $\eta$ representing turbine efficiency, the annual power generation is:

$$
P_{\text {year }}=\int_{0}^{t} P \mathrm{~d} t=\int_{0}^{t} \frac{\rho \eta Q h}{75} \times 0.736^{x} 705 \mathrm{~d} t^{J} \mid \text { year }=70^{0} 32.3 \eta \int_{0}^{t} Q^{h} \mathrm{~d} t .
$$

Only a few tidal power plants in the world are currently generating electricity. It was in Europe that the first commercial tidal power plant was installed. In 1920, UK became the first country to suggest utilising the power of the tides to produce electricity (Kirby and Retière 2009). However, installation of the first commercial tidal power plant was done in France, specifically in Brittany's Rance Estuary in 1967. This power plant was equipped with an installed capacity of $240 \mathrm{MW}$ and was able to supply $4 \%$ of Brittany's domestic electricity supply (Kirby and Retière 2009). The barrage of the plant measured $720 \mathrm{~m}$ long and had a surface area of $22 \mathrm{~km}^{2}$. It served as a road and was fitted with a lock to accommodate shipping passage. The barrage operated with a hydrostatic head of $5 \mathrm{~m}$ and had 24 reversible $10 \mathrm{MW}$ bulb turbines. The power plant was able to produce an annual output of approximately $480 \mathrm{GWh}$ (Segura et al. 2017). The second largest commercial tidal power plant is the Annapolis Royal Generating Station power plant, which was built between 1980 and 1984 in the Bay of Fundy, Canada. With its $20 \mathrm{MW}$ capacity, this power plant is also connected to the Canadian national grid. Its annual generating capacity is $30 \mathrm{GWh}$ (Power 
16-12-2012; Khan et al. 2017), and it utilises only a single Straflo turbine (Mazumder and Arima 2005). The Kislaya Guba power plant has a 0.4 MW capacity and was built on the Barents Sea by the Russian government in 1968. In 2006, it was given an upgrade to use a 1.2 MW orthogonal turbine (Station). In 1985, China constructed the Jiangxia Tidal Power Station in the south of Hangzhou. It has a generation capacity of $3.2 \mathrm{MW}$ and possesses a two-way operational capacity that is capable of producing $4.4 \mathrm{GWh}$ of electrical power annually, as presented in Table 1 (Plant). In 2011, the world's biggest tidal power plant was built by the (South) Korea Water Resources Corporation (K-water). This tidal power plant had an installed capacity of $254 \mathrm{MW}$ and is capable of generating an annual output of 552 GWh (Kang et al. 2013. In 2009, South Korea commissioned the construction of a second tidal power plant (Uldolmok Tidal Power Station) that possesses an installed capacity of 1.5 MW and is able to produce $2.4 \mathrm{GWh}$ per year (project). In 2015, the Netherlands established the Eastern Scheldt Barrier Tidal Power Plant with a generation capacity of $1.25 \mathrm{MW}$. This power plant is capable of providing for the domestic electric supply of approximately 1000 Dutch households (Barrier 2016; Energy 2016). The details of the tidal power plants built around the world so far are given in Table 1, while Table 2 provides the details for the power plants planned for future operation.

Research and development studies regarding ocean energy technology have primarily been performed in Europe by both the EU and its member states. These studies have resulted in improvements in the available technology and improved policies and planning procedures for ocean energy. National and international policymakers need to focus on the successful establishment of a marine energy marketplace that includes provisions for incentives that will encourage the utilisation of tidal energy and help implement strategies to enhance the level of research and technology. Companies must also be encouraged to focus on developing and installing ocean energy technology.

\section{Environmental view and ecological impact}

Some of the environmental impacts associated with tidal energy include risk of collision with migratory and mobile marine species, electromagnetic fields, noise, loss of habitat, reduction in visual amenity, and change in sediment distribution. One possible area

Table 1 Operational tidal power plants (Leeney et al. 2014, Santos et al. 2011, barrier, Station, Kirby and Retière 2009)

\begin{tabular}{llllll}
\hline Power plant & Country & Year & $\begin{array}{l}\text { Installed } \\
\text { capacity } \\
\text { (MW) }\end{array}$ & $\begin{array}{l}\text { Annual } \\
\text { capacity } \\
\text { (GWh) }\end{array}$ & Operation mode \\
\hline Annapolis Royal station & Canada & 1984 & 20 & 30 & Ebb only \\
Jiangxi, tidal station & China & 1980 & 3.2 & 4.4 & Two-way \\
Kislaya & Russia & 1968 & 1.7 & 1.8 & Two-way \\
Rance tidal & France & 1966 & 240 & 480 & Two-way with pumping \\
Sihwa Lake & South Korea & 2011 & 254 & 552 & - \\
Strangford Lough & UK & 2008 & 1.2 & - & - \\
Uldolmok & South Korea & 2009 & 1.5 & 2.4 & - \\
Eastern Scheldt & The Netherlands & 2015 & 1.25 & - & - \\
\hline
\end{tabular}


Table 2 Companies involved worldwide in developing tidal energy (Magagna and Uihlein 2015; Magagna et al. 2016)

\begin{tabular}{|c|c|c|c|}
\hline No. & Company name & Technology & Country \\
\hline 1 & Alstom & Oceade & USA \\
\hline 2 & Andritz Hydro Hammerfest & HS Series & Norway \\
\hline 3 & Aqua Energy Solution & AES & Norway \\
\hline 4 & Atlantis Resources & AK, AR, AS, AN Series & UK \\
\hline 5 & BioPower System & bioSTREAM & Australia \\
\hline 6 & Bluewater & BlueTEC & The Netherlands \\
\hline 7 & Deepwater Energy & Oryon Watermill & The Netherlands \\
\hline 8 & EEL Energy & EEL membrane & France \\
\hline 9 & Elemental Energy Techn. & MAKO turbine & Australia \\
\hline 10 & Flumill & Flumill & Norway \\
\hline 11 & Straum & Hydra Tidal & Norway \\
\hline 12 & Hyundai Heavy Industries & HHI Tidal & South Korea \\
\hline 13 & IHC Tidal Energy & OceanMill & The Netherlands \\
\hline 14 & Kawasaki Heavy Industries & KHI Tidal Turbine & South Korea \\
\hline 15 & Marine Current Turbines & SeaGen & UK \\
\hline 16 & Magallanes & Atir & Spain \\
\hline 17 & Minesto & Deep Green Series & Sweden \\
\hline 18 & Nautricity & CorMaT & UK \\
\hline 19 & New Energy Corporation. & EnCurrent & Canada \\
\hline 20 & Nova Innovation & NOVA series & UK \\
\hline 21 & Ocean Renewable Power Company & TidGen & USA \\
\hline 22 & Oceana Energy Company & Oceana Marine Turbines & USA \\
\hline 23 & Oceanflow Energy & Evopod & UK \\
\hline 24 & OpenHydro (DCNS) & Open-Centre Turbine & Ireland \\
\hline 25 & Pulse Tidal & Pulse-Stream Series & UK \\
\hline 26 & Sabella & D series & France \\
\hline 27 & SCHOTTEL group & SIT Instream & Germany \\
\hline 28 & Scot renewables & SR Series & UK \\
\hline 29 & Tidal Energy & Delta Stream Series & UK \\
\hline 30 & Tidalys & Electrimar series & France \\
\hline 31 & Tocardo & $\mathrm{T}$ series & The Netherlands \\
\hline 32 & Verdant Power & KHPS series & USA \\
\hline 33 & Voith Hydro & HyTide & Germany \\
\hline 34 & Vortex Hydro Energy & VIVACE series & USA \\
\hline
\end{tabular}

that will potentially impart ecological impacts is the generation of electromagnetic fields (EMFs) by submarine cables. These electromagnetic fields may negatively affect the growth, generation, and progress of marine species, as presented in earlier studies (Öhman et al. 2007; Gill and Bartlett 2011). It can also affect carnivorous species that function as predators to marine life. Moreover, due to their effects on navigational equipment, EMFs from sub-sea cables may also influence shipping. However, recent laboratory-based studies on the effects of electromagnetic radiation have found no direct influence on the migration 
or breeding of benthic animals. Furthermore, there has been no effect on elasmobranch fish species like sharks, and it has been found that they generally do not seem to influence their swimming speed. However, these effects can be species specific and there is still no clarity on their overall biological effect (Gill et al. 2012; Westerberg and Lagenfelt 2008). EMF discharges generated by the exploitation of ocean energy are believed to produce very low risks or can even be completely risk-free. However, there is a need to conduct further studies to confirm this (Gill et al. 2012; Leeney et al. 2014).

The ecological impact that ocean energy exploitation has remains unclear since tidal energy devices and ecosystems have complex and progressive interactions over time, which may lead to unforeseen consequences (Lin and Yu 2012; Wilson et al. 2006). Whilst there is knowledge about the ecosystem of the Earth, there is limited knowledge about oceanic ecosystems. Furthermore, obtaining more information on ocean environments can be both expensive and difficult. Projects involving tidal energy only take away a small amount from the ocean's total energy flow. Measuring the indicators of small ecological effects or avoiding such events will be difficult (Wilson et al. 2006; Shields et al. 2011). Due to ecological constraints, the potential for constructing traditional tidal range technology, which involves closing river arms or streams with dams or impoundments, is limited. Moreover, previous experiences with artificially closed compounds have shown that managing an artificial tidal basin involves high costs and requires careful planning and monitoring. It is worth noting that for the Canadian plants, well-documented discussions took place from the beginning of their operation regarding their effects on marine life and how they can be mitigated. This is valuable information since ecological issues pose important conditions and requirements in allowing the installations of such structures in protected water bodies.

\section{Social influences}

A "social gap" is present between public support for renewable energy development that results in local employment opportunities, lower electricity costs, reduced carbon emissions, and increased energy security, and the lesser success of planning and application approvals, which is due to visual impacts, indifference to climate change, the desire to prevent the industrialisation of coastal waters, and harm to tourism, fisheries, recreation, and navigation activities, along with potential impacts on property values as well as social unity. Planning and decision-making can lead to more opposition due to poor engagement with the public. This matter is best settled through improved communication and involvement among all stakeholders, although longer and costlier consultation processes would be involved.

In earlier times, the problems involved with usage of renewable energy sources were not of widespread concern to UK citizens (Walker 1995; Bonar et al. 2015), whereas today some $80 \%$ would support increased reliance on renewable energies. Nevertheless, the degree of utilisation of renewable energy power sources is much lower than the degree of public support present. Likewise, from July 2012 to June 2013, the level of public support among UK citizens for onshore wind generation development correspondingly declined from some 68-59\% for England and down to $46 \%$ for Wales (Bonar et al. 2015). The problem concerns the judgement and intentions of citizens and remains complex (Warren et al. 2005; Bell et al. 2005; Michaud et al. 2008), for much support for renewable energies depends on a mounting public appreciation of environmental responsibility that entails replacement of fossil fuel energy sources with a need to cut greenhouse gas emission levels (Devine-Wright 2011; Ladenburg 2010). For 
one, renewable energy expansions create jobs in provincial areas (Dacre 2007; Bonar et al. 2015), supply low-cost electricity (Devine-Wright 2011), and promote energy conservation (Bell et al. 2005; Ladenburg 2010). Then again, communities in areas where tidal energy facilities have been proposed are wary of the possible harmful effects on local fisheries (West et al. 2009; Kerr et al. 2014), shipping security, deep-sea entertainment, and tourist activities (Bell et al. 2005; McLachlan 2009), along with possible impacts on property values (Warren et al. 2005) and local societies (Firestone and Kempton 2007). Nonetheless, conflicts with local communities can be settled by imparting better knowledge about the operations of tidal energy facilities and also by maximising the role of home-grown contributors. In this manner, the long-term benefits could be shown to be favourable to local districts (Irvin and Stansbury 2004; Cass et al. 2010). Such developments can meet local requirements when unused land is utilised and placed under the ownership of local community, with provisions for systematic distribution of project that proceeds to community members, even if certain negative effects do ensue from project implementation (Cass et al. 2010). However, new proposals may face organised opposition and be forcefully disputed, or could even be suspended, whenever approval processes deadlock (Waldo 2012). Nevertheless, frivolous local objections to such plans can be avoided when people are convinced to act smartly regarding policies that would improve usage of renewable energies (Bonar et al. 2015).

\section{Tidal energy policy}

It has been known that there are a number of contributing government guidelines and industry activities that can propel technology development and utilisation, which can be usually be classified as "technology push", "market pull", and "regulatory push/pull". Other activities that governments carry out are sometimes called "enabling activities", which include activities like environmental analysis, financial support for research, conference hosting, and other such activities. The tidal energy guidelines developed by several nations are not regulated by any global organisations. Meanwhile, several nations have developed their own tidal energy guidelines. Table 3 briefly outlines the tidal energy guidelines of different nations. Figure 4 summarises the global tidal energy policy issues.

Development of the tidal energy has been undertaken in Portugal, Canada, France, the USA, and the UK, and these nations have even defined policies for tidal energy. Globally, tidal energy guidelines fall under the common heading of renewable energy guidelines and most nations have set goals for the increase in the utilisation of renewable energy resources so as to reduce need of fossil fuels and to reduce $\mathrm{CO}_{2}$ emissions (Ozturk et al. 2009). The tidal energy is more environmentally pleasant than more traditional energy sources and is more stable and predictable than other renewable energy sources, as well as being possibly safer. Nonetheless, using a range of renewable energy sources in order to reduce $\mathrm{CO}_{2}$ emissions can potentially make the power produced in these ways economical and viable for use in the industry, therefore leading to financial growth via more efficient production and more employment (do Valle Costa et al. 2008; Sun et al. 2008). 


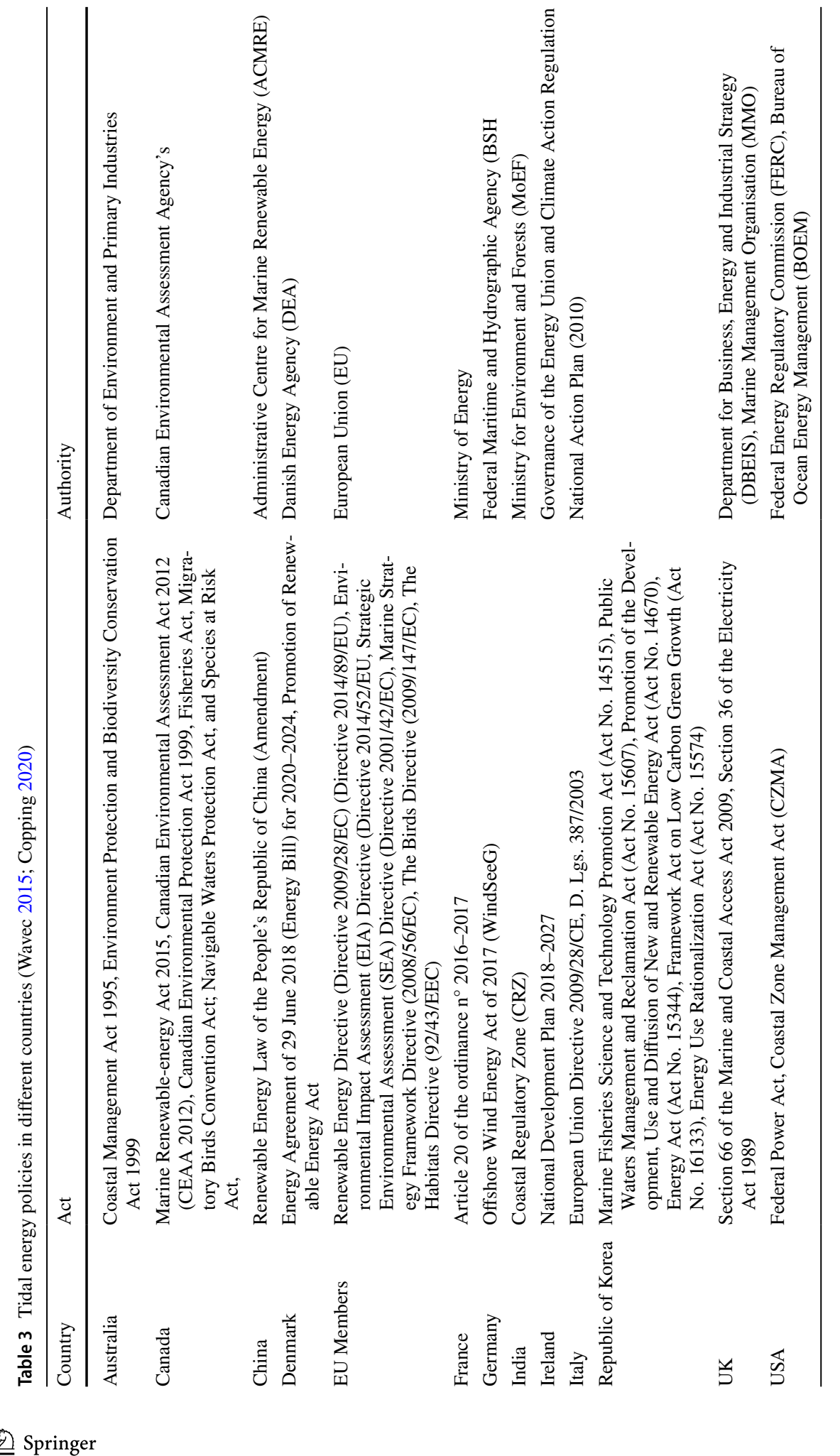




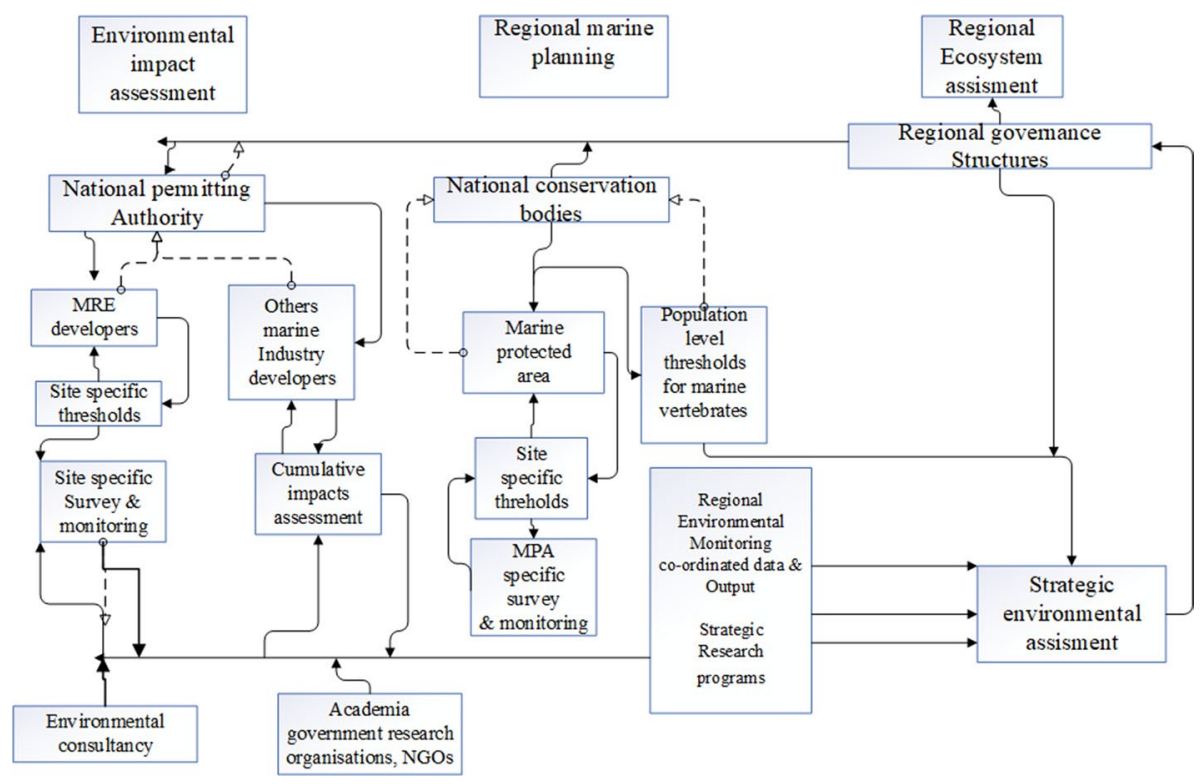

Fig. 4 Global tidal energy policy issues (Fox et al. 2018)

\section{Prospects of tidal energy and proposed power plant}

Currently, tidal dams or barrages are regarded as determined energy tools that are capable of producing electricity on a profitable scale. The research and development $(R \& D)$ in tidal energy is largely in the field of tidal barriers and turbines. The next epoch is likely to witness the tidal energy becoming a fully profitably sustainable energy source, and thus comprehensive research is significant in tidal energy (Ramos and Ringwood 2016; Melikoglu 2018). Nowadays, high quantities of capital funding are provided in order to develop the projects of the tidal stream energy. The electricity production cost from the tidal energy is much greater than that of the conventional energy sources (Melikoglu 2018). Moreover, there are doubts regarding environmental effects of tidal energy equipment installation and its procedure on the marine dwellers and birds in the long duration. The future seems brighter due to the designs of the tidal dams or barrages because the technology has been created roughly since half a century. Nonetheless, it has been stated that there are extensive plans for projects of tidal barrages in Russia, Korea, India, and the UK which amounts to nearly 115 GW in total (Ramos and Ringwood 2016), and deployment predictions for tidal energy up to 2020 are nearly about 200 MW (IRENA 2014). Table 4 presents the globally proposed tidal power stations.

Tidal energy could generate electricity, though there are certain challenges in its development and in promotion of awareness of ocean energy resources, and bring an increase in their present potential. Challenges in the development of tidal energy are shown in Fig. 5. Further research could identify these challenges, and nations, oceanic and maritime services, industry, research organisations, and universities are required to obtain an integrated and coordinated methodology, so as to obtain robust, viable, and cost-efficient tidal energy. Nonetheless, increasing affordability could shift the innovation, incentive, and cost reduction towards other alternative energy sources. 
Table 4 Globally planned tidal power stations (Ko et al. 2019, Newenergyupdate, 15.12.15, EnergyNews, Project, walesonline, Tidallagoonpower, BBC, 10 April 2014)

\begin{tabular}{llll}
\hline Name & Capacity (MW) & Country & Primary cost (\$) \\
\hline Garorim bay tidal power station & 520 & South Korea & 1 billion \\
Incheon tidal power station & 1320 & South Korea & 3.4 billion \\
Tugurskaya tidal power plant & 3640 & Russia & - \\
Mezenskaya tidal power plant & 24,000 & Russia & 22.76 billion \\
Skerries tidal stream array & 10.5 & UK & 0.07698 billion \\
Tidal lagoon Swansea bay & 320 & UK & 1.3 billion \\
Gulf of Kutch project & 50 & India & 0.15 billion \\
Alderney tidal plant & 300 & Alderney & 0.830 billion \\
\hline
\end{tabular}

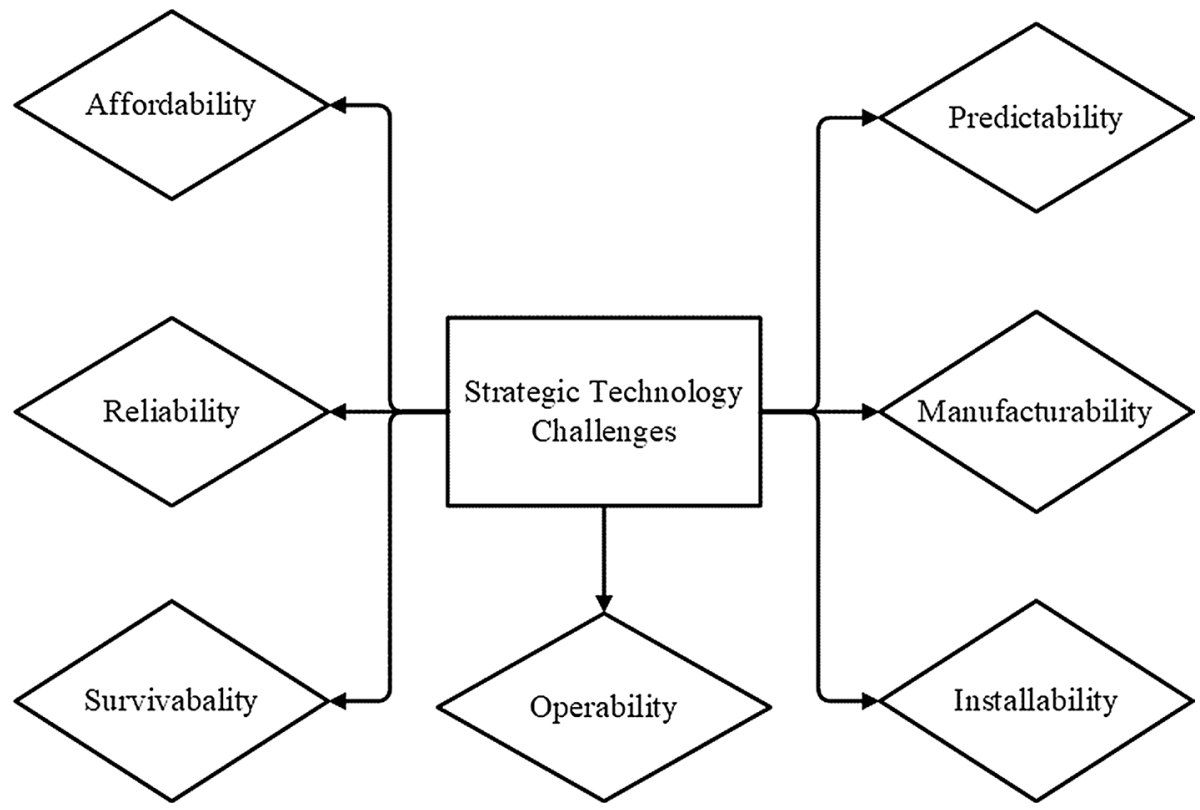

Fig. 5 Challenges in the development of tidal energy (Energy, December 2012)

Predictability has emphasised the problem of considering the impacts of turbulence and their influence in the fatigue life of the component. Consequently, it could be a contributing aspect in reducing the unforeseen conservation requirements by performing more comprehensive studies on factors such as specific components of the MTBF (mean time between failure) as well as life expectation, developing the manufacturability of tidal energy converters from first-scale prototype to profitable manufacture. This will affect the design of important modules and sub-elements in supplement to expansion of the manufacturing procedure. Moreover, study of the new materials as alternatives for steel indicates high cost reductions along with a decrease in the dimensions of the established modules. The definition of new regulation techniques and operating and testing practices will help the distant survivability and operability of the tidal energy technologies that function under extreme circumstances. Providing inexpensive automation methods 
with less human involvement will allow low-cost multipurpose ships instead of highcost extraordinary vessels, so as to optimise setting up and maintenance expenses.

\section{Conclusion}

In theory, the ocean has abundant energy store, the utilisation of which requires the creation of innovations to make the tidal energy a useful source of secured energy with which to fill the lack of energy, and decreasing global $\mathrm{CO}_{2}$ emissions resulting from the use of fossil fuels. This study summarises the present trends and further potential of the tidal energy platform, though it is required that tidal power stations produce energy in the range of hundreds of thousands of megawatts to gigawatts of power to compete with the production capacity of other conventional and nonconventional sources of energy. Thus, it is crucial to evaluate accurately the usefulness of the working of various pieces of powerproducing equipment with respect to the amount of power supply to the electrical grid. A better insight into the tidal energy and various devices available to exploit it will lead to enhanced equipment design. Tidal energy is a pollution-free natural and renewable energy source with only a negligible environmental impact. Nonetheless, the effect of marine energy exploitation on the environment is required to be entirely understood to make sure that there are no hindrances to large-scale utilisation. A more integrated engineering design methodology is vital to optimise the usage of materials, science, and recent manufacturing methods. Finally, the goal of future exploration is to develop technology that leads to integrated grid networks from offshore transmission lines while decreasing setting up costs and environmental effects.

Acknowledgements The authors would like to acknowledge and appreciate the contribution of The Solar Energy Research Institute of The National University of Malaysia (UKM) through the research Grant Number GUP-2017-031. Due appreciation is also credited to the Institute of Sustainable Energy (ISE) of the Universiti Tenaga Nasional (The National Energy University) of Malaysia for their valuable support through the BOLD2025 Programme. The authors also acknowledge the contribution of Thailand's Education Hub for Southern Region of ASEAN Countries Project (THE-AC) with Code Number THE-AC 062/2017.

\section{References}

Abiad, A. A., \& Rosa Mia Dagli, S. (2020). The economic impact of the COVID-19 outbreak on developing Asia. Adrian 2020. Renewable Capacity Statistics 2020.

April 10, 2014. OpenHydro to Build \$833 Million Tidal-Power Plant in Alderney. https://www.bloomberg. com/news/articles/2014-04-10/openhydro-to-build-833-million-tidal-power-plant-in-alderney.

Badcock-Broe, A., Flynn, R., George, S., Gruet, R., \& Medic, N. (2014). Wave and tidal energy market deployment strategy for Europe. In Strategic Initiative for Ocean Energy (SI Ocean). http://www.siocean.eu/en/Market-Deployment/MarketDeployment-Strategy.

Barrier, E. S. S. S. (2016). Eastern Scheldt storm surge barrier. https://www.dutchwatersector.com/news/ tocardo-to-place-tidal-energy-turbines-in-eastern-scheldt-storm-surge-barrier-the-netherlands.

BBC. India plans Asian tidal power first. $B B C$.

Behrens, S., Hayward, J. A., Woodman, S. C., Hemer, M. A., \& Ayre, M. (2015). Wave energy for Australia's national electricity market. Renewable Energy, 81, 685-693.

Bell, D., Gray, T., \& Haggett, C. (2005). The 'social gap' in wind farm siting decisions: Explanations and policy responses. Environmental politics, 14, 460-477.

Bonar, P. A., Bryden, I. G., \& Borthwick, A. G. (2015). Social and ecological impacts of marine energy development. Renewable and Sustainable Energy Reviews, 47, 486-495. 
Buhali, M. L., Abundo, M. L. S., \& Ang, M. R. C. O. (2012). Site selection procedures for tidal in-stream energy in the Philippines: A preliminary study. In 2012 10th international power \& energy conference (IPEC) (pp. 110-114). IEEE.

Cass, N., Walker, G., \& Devine-Wright, P. (2010). Good neighbours, public relations and bribes: The politics and perceptions of community benefit provision in renewable energy development in the UK. Journal of Environmental Policy \& Planning, 12, 255-275.

Chen, W.-B., Liu, W.-C., \& Hsu, M.-H. (2013). Modeling assessment of tidal current energy at Kinmen Island, Taiwan. Renewable Energy, 50, 1073-1082.

Coles, D., Blunden, L., \& Bahaj, A. (2017). Assessment of the energy extraction potential at tidal sites around the Channel Islands. Energy, 124, 171-186.

Copping, A. H. L. (2020). OES-environmental 2020 state of the science report: Environmental effects of marine renewable energy development around the world.

Do Valle Costa, C., La Rovere, E., \& Assmann, D. (2008). Technological innovation policies to promote renewable energies: Lessons from the European experience for the Brazilian case. Renewable and Sustainable Energy Reviews, 12, 65-90.

Dacre, S. L. (2007). The environmental impacts and developmental constraints of tidal Current energy generation. Robert Gordon University.

Devine-Wright, P. (2011). Enhancing local distinctiveness fosters public acceptance of tidal energy: A UK case study. Energy Policy, 39, 83-93.

Dorn, F., Fuest, C., Göttert, M., Krolage, C., Lautenbacher, S., et al. (2020). The economic costs of the coronavirus shutdown for selected european countries: A scenario calculation. EconPol Policy Brief.

Energy, A. I. V. F. O. (2016). An international vision for ocean energy.

Energy, O. December 2012. State of the Art. SI Ocean. http://si-ocean.eu/en/upload/docs/WP3/Technology StatusReport_FV.pdf.

Energynews. In: Energy, E. Q. R. P. O. A. (Ed.).

Esteban, M., \& Leary, D. (2012). Current developments and future prospects of offshore wind and ocean energy. Applied Energy, 90, 128-136.

Firestone, J., \& Kempton, W. (2007). Public opinion about large offshore wind power: Underlying factors. Energy Policy, 35, 1584-1598.

Fox, C. J., Benjamins, S., Masden, E. A., \& Miller, R. (2018). Challenges and opportunities in monitoring the impacts of tidal-stream energy devices on marine vertebrates. Renewable and Sustainable Energy Reviews, 81, 1926-1938.

Gao, P., Zheng, J., Zhang, J., \& Zhang, T. (2015). Potential assessment of tidal stream energy around Hulu Island, China. Procedia Engineering, 116, 871-879.

Gill, A., Bartlett, M., \& Thomsen, F. (2012). Potential interactions between diadromous fishes of UK conservation importance and the electromagnetic fields and subsea noise from marine renewable energy developments. Journal of Fish Biology, 81, 664-695.

Gill, A. B., \& Bartlett, M. D. (2011). Literature review on the potential effects of electromagnetic fields and subsea noise from marine renewable energy developments on Atlantic salmon, sea trout and European eel. Scottish Natural Heritage Commissioned Report.

González-Caballín, J. M., Álvarez, E., Guttiérrez-Trashorras, A. J., Navarro-Manso, A., Fernández, J., \& Blanco, E. (2016). Tidal current energy potential assessment by a two dimensional computational fluid dynamics model: The case of Avilés port (Spain). Energy Conversion and Management, 119, 239-245.

Guillou, N., Neill, S. P., \& Robins, P. E. (2018). Characterising the tidal stream power resource around France using a high-resolution harmonic database. Renewable Energy, 123, 706-718.

Hale, T., Webster, S., Petherick, A., Phillips, T., \& Kira, B. (2020). Oxford Covid-19 government response tracker. Blavatnik School of Government, 25.

IEA. (2020a). Global Energy Review 2020.

IEA. (2020b). Ocean power generation in the Sustainable Development Scenario, 2000-2030.

IRENA. (2014). Tidal Energy Technology Brief.

Irvin, R. A., \& Stansbury, J. (2004). Citizen participation in decision making: Is it worth the effort? Public Administration Review, 64, 55-65.

Jeffrey, A. B. E. M. A. H. (2017). Annual report an overview of activities in 2017.

Kadiri, M., Ahmadian, R., Bockelmann-Evans, B., Rauen, W., \& Falconer, R. (2012). A review of the potential water quality impacts of tidal renewable energy systems. Renewable and Sustainable Energy Reviews, 16, 329-341.

Kang, N. S., Lee, K. H., Jeong, H. J., Du Yoo, Y., Seong, K. A., Potvin, É., et al. (2013). Red tides in Shiwha Bay, western Korea: A huge dike and tidal power plant established in a semi-enclosed embayment system. Harmful Algae, 30, S114-S130. 
Kerr, S., Watts, L., Colton, J., Conway, F., Hull, A., Johnson, K., et al. (2014). Establishing an agenda for social studies research in marine renewable energy. Energy Policy, 67, 694-702.

Khan, N., Kalair, A., Abas, N., \& Haider, A. (2017). Review of ocean tidal, wave and thermal energy technologies. Renewable and Sustainable Energy Reviews, 72, 590-604.

Kirby, R., \& Retière, C. (2009). Comparing environmental effects of Rance and Severn barrages. In Proceedings of the Institution of Civil Engineers-Maritime Engineering (pp. 11-26). Thomas Telford Ltd.

Ko, D.-H., Chung, J., Lee, K.-S., Park, J.-S., \& Yi, J.-H. (2019). Current policy and technology for tidal current energy in Korea. Energies, 12, 1807.

Ladenburg, J. (2010). Attitudes towards offshore wind farms-The role of beach visits on attitude and demographic and attitude relations. Energy Policy, 38, 1297-1304.

Leeney, R. H., Greaves, D., Conley, D., \& O’Hagan, A. M. (2014). Environmental impact assessments for wave energy developments-Learning from existing activities and informing future research priorities. Ocean and Coastal Management, 99, 14-22.

Li, Y. (2008). Development of ocean energy. Beijing: China Ocean Press. (in Chinese).

Lim, Y. S., \& Koh, S. L. (2010). Analytical assessments on the potential of harnessing tidal currents for electricity generation in Malaysia. Renewable Energy, 35, 1024-1032.

Lin, L., \& Yu, H. (2012). Offshore wave energy generation devices: Impacts on ocean bio-environment. Acta Ecologica Sinica, 32, 117-122.

Magagna, D., Monfardini, R., \& Uihlein, A. (2016). JRC ocean energy status report 2016 edition. Luxembourg: Publications Office of the European Union.

Magagna, D., \& Uihlein, A. (2015). Ocean energy development in Europe: Current status and future perspectives. International Journal of Marine Energy, 11, 84-104.

Mazumder, R., \& Arima, M. (2005). Tidal rhythmites and their implications. Earth-Science Reviews, 69, 79-95.

Mclachlan, C. (2009). 'You don't do a chemistry experiment in your best China': Symbolic interpretations of place and technology in a wave energy case. Energy Policy, 37, 5342-5350.

Melikoglu, M. (2018). Current status and future of ocean energy sources: A global review. Ocean Engineering, 148, 563-573.

Michaud, K., Carlisle, J. E., \& Smith, E. R. (2008). Nimbyism vs. environmentalism in attitudes toward energy development. Environmental Politics, 17, 20-39.

Moore, T., \& Boyle, C. (2014). The tidal energy potential of the Manukau Harbour, New Zealand. Sustainable Energy Technologies and Assessments, 8, 66-73.

Newell, R. G., Daniel, R., \& Aldana, G. (2019). World Energy Outlook 2019.

Newenergyupdate 15.12.15.

Öhman, M. C., Sigray, P., \& Westerberg, H. (2007). Offshore windmills and the effects of electromagnetic fields on fish. AMBIO: A journal of the Human Environment, 36, 630-634.

Orhan, K., Mayerle, R., \& Pandoe, W. W. (2015). Assessment of energy production potential from tidal stream currents in Indonesia. Energy Procedia, 76, 7-16.

Ozturk, M., Bezir, N. C., \& Ozek, N. (2009). Hydropower-water and renewable energy in Turkey: Sources and policy. Renewable and Sustainable Energy Reviews, 13, 605-615.

Power, N. S. 16-12-2012. Annapolis Tidal Station. https://tethys.pnnl.gov/annex-iv-sites/annapolis-tidal -station.

Plant, J. P. T. P. Jiangxia Pilot Tidal Power Plant. https://tethys.pnnl.gov/annex-iv-sites/jiangxia-pilot -tidal-power-plant.

Project, J. U. T. Jindo Uldolmok tidal project. https://www.hydroreview.com/2009/05/29/south-korea -starts/\#gref.

Project, M. T. Mezen Tidal Project. http://www.carbonsc.com/cscb/?page_id=348.

Ramos, V., \& Ringwood, J. V. (2016). Implementation and evaluation of the International Electrotechnical Commission specification for tidal stream energy resource assessment: A case study. Energy Conversion and Management, 127, 66-79.

Rourke, F. O., Boyle, F., \& Reynolds, A. (2010). Tidal energy update 2009. Applied Energy, 87, 398-409.

Santos, M., Salcedo, F., Haim, D. B., Mendia, J., Ricci, P., et al. (2011). Integrating wave and tidal current power: Case studies through modelling and simulation.

Segura, E., Morales, R., Somolinos, J., \& López, A. (2017). Techno-economic challenges of tidal energy conversion systems: Current status and trends. Renewable and Sustainable Energy Reviews, 77, 536-550.

Shields, M. A., Woolf, D. K., Grist, E. P., Kerr, S. A., Jackson, A., Harris, R. E., et al. (2011). Marine renewable energy: The ecological implications of altering the hydrodynamics of the marine environment. Ocean and Coastal Management, 54, 2-9. 
Station, K. G. T. P. Kislaya Guba Tidal Power Station. https://www.revolvy.com/page/Kislaya-Guba-Tidal -Power-Station.

Sun, X., Chick, J., \& Bryden, I. (2008). Laboratory-scale simulation of energy extraction from tidal currents. Renewable Energy, 33, 1267-1274.

TIDALLAGOONPOWER swansea-bay.

Waldo, Å. (2012). Offshore wind power in Sweden-A qualitative analysis of attitudes with particular focus on opponents. Energy Policy, 41, 692-702.

Walesonline. $£ 70 \mathrm{~m}$ Skerries tidal project gets second lease of life as Atlantis buys Marine Current Turbines. https://www.walesonline.co.uk/business/business-news/70m-skerries-tidal-project-gets-9160142.

Walker, G. (1995). Renewable energy and the public. Land Use Policy, 12, 49-59.

Warren, C. R., Lumsden, C., O’Dowd, S., \& Birnie, R. V. (2005). 'Green on green': Public perceptions of wind power in Scotland and Ireland. Journal of Environmental Planning and Management, 48, 853-875.

Wavec. (2015). Consenting Processes for Ocean Energy on OES Member Countries. https://tethys.pnnl.gov/ sites/default/files/publications/OES-AnnexI-Report-2015.pdf.

West, J., Bailey, I., \& Whithead, I. (2009). Stakeholder perceptions of the Wave Hub development in Cornwall, UK. European Wave and Tidal Technology Conference (EWTEC). Uppsalla, Sweden: School of Geography, Earth and Environmental Sciences, University of Plymouth, 2009.

Westerberg, H., \& Lagenfelt, I. (2008). Sub-sea power cables and the migration behaviour of the European eel. Fisheries Management and Ecology, 15, 369-375.

Wilson, B., Batty, R., Daunt, F., \& Carter, C. (2006). Collision risks between marine renewable energy devices and mammals, fish and diving birds: Report to the Scottish executive.

Publisher's Note Springer Nature remains neutral with regard to jurisdictional claims in published maps and institutional affiliations. 